\title{
Women Entrepreneurship in India: An Insight into Problems, Prospects and Development
}

\author{
Chinmayee Sahoo \\ Dept of sociology, Utkal University \\ Bhubaneswar, India
}

\begin{abstract}
Development has economic, social and political dimensions and is incomplete without the development of women who constitute about 50 per cent of total population. So, contribution of women is essential in economic activities for healthy nation building. When we speak about the term "Women Entrepreneurship" we mean, an act of business ownership and business creation that empowers women economically, increases their economic strength as well as position in society. Hence women-entrepreneurs have been making a considerable impact in all most all the segments of the economy which is more than $25 \%$ of all kinds of business. As per statistics it is known that in well-developed economy women is having freedom to develop as an entrepreneur, they are having equal priority as equal as man, but in developing economy and under developed economies women are facing different types of problems. Development of women has been a policy objective of the government since independence. Women were given priorities in all the sectors including SSI sector. Government and non-government bodies have paid increasing attention to women's economic contribution through selfemployment and industrial ventures. Right efforts from all areas are required in the development of women entrepreneurs and their greater participation in the entrepreneurial activities. Women entrepreneurship must be moulded properly with entrepreneurial traits and skills to meet the changes in trends, challenges of the global markets and also be competent enough to sustain and strive for excellence in the entrepreneurial arena.
\end{abstract}

Key words: Women entrepreneurship, problem, prospect, development

\section{INTRODUCTION}

Entrepreneurship is necessary to initiate the process of economic development of both developed and developing countries as it is the back bone of economy of any country. Entrepreneurship refers to combining the available resources of production in such a new way that it produces the goods and services more satisfactory to the customers. Entrepreneur is a catalytic agent of change. It is also instrumental in sustaining the process of economic development. Every country tries to achieve economic development for prosperity and better life standard of its people. Development has economic, social and political dimensions and is incomplete without the development of women who constitute about 50 per cent of total population. So, contribution of women is essential in economic activities for healthy nation building.

A person who assumes and bears all types of risks involved in an enterprise, who organizes the various inputs or factors of production and who innovates news ideas, concepts, strategies and methodology in business from time to time is known as Entrepreneur.

\section{WOMEN ENTREPRENEURSHIP}

When we speak about the term "Women Entrepreneurship" we mean, an act of business ownership and business creation that empowers women economically, increases their economic strength as well as position in society. Hence women-entrepreneurs have been making a considerable impact in all most all the segments of the economy which is more than $25 \%$ of all kinds of business. In India "Entrepreneurship" is very limited amongst women especially in the formal sector, which is less than $5 \%$ of all the business.

Women are one particularly understudied group of entrepreneurs. We know very little about female entrepreneurs, and our ignorance of this important demographic is a serious blind spot in any effort to increase the total number of entrepreneurs participating in our economy.

Today, more and more women are undertaking various economic activities. Female entrepreneurs are active at all levels domestically, regionally and globally. Women entrepreneurs encounters only one third of all entrepreneurs. In the era of globalization, the challenges are far greater for women entrepreneurs. They are playing very important role in socio-economic development of all countries. Because of their participation, global economy is being changed at present. All over the world, it is estimated that approximately one third of the business organizations are owned by women. In India, the position is near about the same. The precious contribution of women in the area of entrepreneurship can be summarized as: 1. Promotion of capital formation by mobilizing the idle saving of the public 2. Creation of immediate employment so it helps to reduce unemployment problem 3. Promotion of balanced regional development 4. Encourage effective mobilization of capital and skill, which might remain unutilized 5. Promotion of India's export trade.

\subsection{Characteristics of Woman Entrepreneur in India}

A woman or a group of women manages the whole business of enterprise. She prepares various plans and executes them under her own supervision and control. A woman entrepreneur takes calculated risk. She faces uncertainty confidently and assumes risk. She has to tie up capital and wait for good returns. The most critical skill required for industrial development is the ability of building a sound organization. A woman entrepreneur assembles, co- 
ordinates, organizes and manages the other factors namely land, labour and capital. It is essential to be a self confident for a woman entrepreneur. She should have faith in herself and in her abilities. The main function of a woman entrepreneur is to make decision. She takes various decisions regarding the activities of her enterprise. She decides about the type of business to be done and the way of doing it. A woman entrepreneur must be clear and creative in decision making process. A distinguishing feature of a woman entrepreneur is the willingness to work hard. She has to follow the principle, "Hard-work is the key to success". A woman entrepreneur must be optimistic. She should approach her venture with a hope of success and attitude for success rather than with a fear of failure.

Women entrepreneurs face the adversities boldly and bravery. She has faith in herself and attempts to solve the problems even under great pressure. A woman entrepreneur is energetic, single-minded, having a mission and a clear vision. She should be a lady of creative thinking and analytical thinking. She must be intelligent, adaptable and problem solver. Leadership quality is one of the most important characteristic of a woman entrepreneur. It is the process of influencing and supporting others to work enthusiastically towards achieving objectives.

\section{IMPORTANCE OF THE STUDY}

World economy of the country is classified into developed economy, developing economy and underdeveloped economy. As per statistics it is known that in well-developed economy women is having freedom to develop as an entrepreneur, they are having equal priority as equal as man, but in developing economy and under developed economies women are facing different types of problem, though government introduces different types of schemes for the sake of women. women are growing well day by day in all sectors and in all areas. Their contributions are more as scientists, software engineers, technocrats, economists, professors, lawyers, doctors and as a businessman also. So, it is clear evidence that women contribution for economy is essential and considerable.

\section{OBJECTIVES OF THE STUDY}

The study is based on secondary data which is collected from the published reports of RBI, NABARD, Census Surveys, SSI Reports, Newspapers, Journals, websites, etc. The study was planned with the following objectives

- To evaluate the factors responsible for encouraging women to become entrepreneurs

- To critically examine the problems faced by women entrepreneurs

- To study the impact of assistance by the government on women's entrepreneurship.

- To provide solutions to the various problems faced by the women entrepreneur group

\section{REVIEW OF LITERATURE}

- V Krishnamoorthy and R Balasubramanian (April 2014), identified the important women entrepreneurial motivation factors and its impact on entrepreneurial success. The study identified ambition, skills and knowledge, family support, market opportunities, independence, government subsidy and satisfaction are the important entrepreneurial motivational factors. The study also concluded that _ambition ', knowledge and skill ', independence 'dimensions of entrepreneurial motivational has significant impact on entrepreneurial success.

- Dr. Sunil Deshpande\& Ms. Sunita Sethi, Shodh, SamikshaaurMulyankan (Oct.-Nov.-2009) in their research paper exhibits the encouraging and discouraging factors in an enterprise and to provide solutions to the various problems faced by the women entrepreneur group. For the betterment of women entrepreneur emphasize should be on educating women strata of population, spreading awareness and consciousness amongst women to outshine in the enterprise field, making them realize their strengths, and important position in the society and the great contribution they can make for their industry as well as the entire economy.

- Singh, Surinder Pal, (2008) in this study identifies the reasons and influencing factors behind entry of women in entrepreneurship. He mentioned the obstacles in the growth of women entrepreneurship are mainly lack of interaction with successful entrepreneurs, social un-acceptance as women entrepreneurs, family responsibility, gender discrimination, missing network, low priority given by bankers to provide loan to women entrepreneurs. He suggested the remedial measures like promoting micro enterprises, unlocking institutional frame work, projecting and pulling to grow and support the winners etc.

- Gurendra Nath Bhardwaj, Swati Parashar, Dr. Babita Pandey and Puspamita Sahu in this study revealed the major hurdles that the women face during starting and running a company generally come from financing and balancing of life. The other hindering external factors include gender discrimination, inaccessibility to information, training opportunities, infrastructure etc. Some internal factors like risk aversion by women, lack of confidence, lack of vision of strategic leader etc. can also create obstacles for the women entrepreneurship development. This study suggested that government should set some priorities for women entrepreneurs for allocation of industrial plots, sheds and other amenities, and precautionary measures should be undertaken to avoid the misuse of such facility by the men in the name of the women.

- According to Deshpande Sunil and Sethi Sunita, (2009) some school of thought they conclude that, now India is in better position because of introduction of women as an entrepreneur. This is mainly because of change of attitude of people towards women., courageous and risk-taking capabilities of women, support from society people, changes and relaxations in government policies, granting various upliftment schemes to women entrepreneurs etc. extension to these findings there are certain other factors which 
facilitates to get success as an entrepreneur as explained in this paper.

- $\quad$ Singh and Raina (2013) described the problems and challenges faced by women entrepreneurs in India and also analysed the policies of Indian government for women. The study mainly focused to find out the status of women entrepreneurs in India. The study found that in modern India, more and more women are taking up entrepreneurial activity especially in MSMEs. It also observed that Indian women have imprinted a position for themselves in the male dominated world. It further showed that Indian women can well manage their household work as well their workplace deadlines.

- According to Roshan Lal and Badri Narayan H.S (2011) some analytical frame work, women Entrepreneurs are essential for achieving for the economic growth of the nation. There are certain obstacles which hinder the growth of the nation should be avoided. Encouragement should be in such a manner which allows women to participate and to take up all kinds of business as an entrepreneur. Government should provide proper training to women entrepreneurs. Government should use sophisticated methods to impart knowledge in all functional areas. Promoting Women entrepreneurship is surely a successful path to develop Indian economy. Apart from these women required psychological motivation also.

\section{METHODOLOGY OF STUDY}

The paper work is based on extensive study of secondary data collected from various books, National \& International Journals and public and private publications available on various websites and in libraries focusing on various aspects of Women Entrepreneurship.

\section{PROBLEMS OF WOMEN ENTREPRENEURSHIP IN INDIA}

$>$ PROBLEM OF FINANCE: Finance is regarded as "life blood" for any enterprise, be it big or small. However, women entrepreneurs suffer from shortage of finance on two counts. Firstly, women do not generally have property on their names to use them as collateral for obtaining funds from external sources. Thus, their access to the external sources of funds is limited. Secondly, the banks also consider women less credit- worthy and discourage women borrowers on the belief that they can at any time leave their business. Given such situation, women entrepreneurs are bound to rely on their own savings, if any and loans from friends and relatives who are expectedly merger and negligible. Thus, women enterprises fail due to the shortage of finance.

$>$ SCARCITY OF RAW MATERIAL: Most of the women enterprises are plagued by the scarcity of raw material and necessary inputs. It is added to this are the high prices of raw material, on the other.

$>$ STIFF COMPETITION: Women entrepreneurs do not have organization set- up to pump in a lot of money for canvassing and advertisement. Thus, they have to face a stiff competition for marketing their products with both organized sector and their male counterparts. Such a competition ultimately results in the liquidation of women enterprises.

$>$ FAMILY TIES: In India, it is mainly a woman's duty to look after the children and other members of the family. Man plays a secondary role only. In case of married woman, she has to strike a fine balance between her business and family. Her total involvement in family leaves little or no energy and time to devote for business. Support and approval of husbands seem necessary condition or women's entry in to business. Accordingly, the educational level and family background of husbands positively influence women's entry into business activities.

$>$ LACK OF EDUCATION: In India, majority of women are still illiterate. Illiteracy is the root cause of socio- economic problems. Due to the lack of education, women are not aware of business, technology and market knowledge. Also, lack of education cases low achievement motivation among women. Thus, lack of education creates problems for women in the setting up and running of business enterprises.

$>$ MALE DOMINATED SOCIETY: Male chauvinism is till the order of the day in India. The constitution of India speaks of equality between genders. But, in practice women are looked upon as able i.e. weak in all respects. Women suffer from male reservations about a women's role, ability and capacity and are treated accordingly. In nutshell, in the male dominated Indian society, women are not treated equal to men. This in turn, serves as a barrier to women entry into business.

$>$ LOW RISK- BEARING ABILITY: Women in India lead a protected life. They are less educated and economically not self- dependent. All these reduce their ability to bear risk involved in running an enterprise. Risk bearing is an essential requisite of a successful entrepreneur. In addition to above problems, inadequate infra structural facilities, shortage of power, high cost of production, social attitude, low need for achievement and socio- economic constraints also hold the women back from entering into business.

$>$ MARKETING PROBLEMS: During the process of marketing of products women entrepreneurs faced certain problems viz. poor location of shop, lack of transport facility and tough competition from larger and established units. 


\section{> PRODUCTION PROBLEMS: Production} problems faced by maximum women are non-availability of raw material. Non-availability of raw material is one of the reasons to the slow growth of women entrepreneurs. Other production problems are non-availability of machine or equipment, lack of training facility and nonavailability of labour, high cost of required machine or equipment.

> HEALTH PROBLEMS: Major health problems faced by women entrepreneurs were tension, backache, eyestrain fatigue and headache. It is found that women feeling the problem of feeling fatigued after returning home, lack of rest and sleep and heavy schedule. Enterprise. Risk bearing is an essential requisite of a successful entrepreneur. In addition to above problems, inadequate infra structural facilities, shortage of power, high cost of production, social attitude, low need for achievement and socio- economic constraints also hold the women back from entering into business.

$>$ FINANCIAL PROBLEMS: Finance is a most important aspect of any business. Nonavailability of long-term finance, regular and frequent need of working capital and long procedure to avail financial help is found to be the financial problems faced by women

\section{ROLE OF GOVERNMENT, INSTITUTIONS FOR PROMOTING WOMEN ENTRENUERSHIP PROGRAMMES IN INDIA}

Development of women has been a policy objective of the government since independence. Women were given priorities in all the sectors including SSI sector. Government and non-government bodies have paid increasing attention to women's economic contribution through self-employment and industrial ventures. The First Five-Year Plan (1951-56) envisaged a number of welfare measures for women. Establishment of the Central Social Welfare Board, organization of Mahila Mandals and the Community Development Programmes were a few steps in this direction. In the second Five-Year Plan (1956-61), the empowerment of women was closely linked with the overall approach of intensive agricultural development programmes. The Third and Fourth FiveYear Plans (1961-66 and 1969-74) supported female education as a major welfare measure. The Fifth Five-Year Plan (1974-79) emphasized training of women, who were in need of income and protection. The Eight Five-Year Plan (1992-97) focused on empowering women, especially at the Gross Roots Level, through Panchayati Raj Institutions. The Ninth Five-Year Plan (1997-2002) adopted a strategy of Women's Component Plan, under which not less than 30 percent of funds were earmarked for women related sectors. The Tenth Five-Year Plan (2002-07) aims at empowering women through translating the recently adopted National Policy for Empowerment of Women (2001) into action and ensuring Survival, Protection and Development of women and children through rights-based approach. At present, the Government of India has over 27 schemes for women operated by different departments and ministries. Some of these are: • Integrated Rural Development Programme (IRDP);

- Khadi And Village Industries Commission (KVIC) ;

- Training of Rural Youth for Self-Employment (TRYSEM)

- Prime Minister's Rojgar Yojana (PMRY)

- Entrepreneurial Development programme (EDPs)

- Management Development progammes;

- Women's Development Corporations (WDCs);

- Marketing of Non-Farm Products of Rural Women (MAHIMA);

- Assistance to Rural Women in Non-Farm Development (ARWIND)

- Trade Related Entrepreneurship Assistance and Development (TREAD);

- Indira Mahila Yojana ; Indira Mahila Kendra; NGO's Credit Schemes; Micro \& Small Enterprises Cluster Development Programmes (MSE-CDP);

- National Banks for Agriculture and Rural Development's Schemes; Rajiv Gandhi Mahila Vikas Pari yojana (RGMVP);

- Priyadarshini Project- A programme for Rural Women Empowerment and Livelihood in Mid Gangetic Plains; Exhibitions for women, under promotional package for Micro \& Small enterprises approved by CCEA under marketing support.

\section{SUGGESTIONS FOR THE DEVOLOPMENT OF WOMEN ENTREPRENEURSHIP IN INDIA}

Right efforts from all areas are required in the development of women entrepreneurs and their greater participation in the entrepreneurial activities. Entrepreneurship basically implies being in control of one's life and activities and women entrepreneurs need to be given confidence, independence, and mobility to come out of their paradoxes. The following measures are suggested to empower the women to seize various opportunities and face challenges in business.

- Finance cells: A large number of various finance cells may be open to provide easy finance to women entrepreneurs. These special cells should provide finance to women entrepreneurs at low and concessional rates of interest and on easy repayment facilities. Even these finance cells should manned by women officers and clerks. Efforts should be made to provide finance at the local level.

- Marketing Co-operatives: Marketing co-operatives should be established to encourage and assist to women entrepreneurs. Government should give preference to women entrepreneurs while purchasing their requirements. These marketing cooperating will help the women entrepreneurs to sell their products on remunerative prices. This will help in eliminating the middlemen. 
- Supply of raw-materials: The required, scare and imported raw-materials should be made available to women entrepreneurs at priority basis at concessional rate.

- Educational and awareness: The educational and awareness programmers should be arranged to change the negative social attitudes towards women. The attitude of elders needs to be changed about the potential of girls and their due role in society.

- Training facilities: Training and developments programmers play very essential role for the development of entrepreneurship. Special training schemes should be so designed that women can get full advantages. Mobile training centres, part time training facilities etc. should be offered to attract more and more women to the training centres.

- Develop a Blue Print: Wesman said one of the top issues she experiences with women entrepreneurs is that they lack having a set plan in place because so many women fall into their business accidentally. "They seem to fall into the business because it's something they like doing, so they don't create a specific plan or strategy," she said. Wesman advised all women entrepreneurs to write up a business blue print when starting out that includes a clear description of the product or service, their target audience and how the business will be run on a daily basis. This blueprint should also touch on the specific responsibilities of the business owner and employees, as well as an estimate of what it will cost to run the business in the first year.

- Team Building: Many female entrepreneurs try to handle every aspect of the business alone, according to Wesman, and that's a recipe for failure. It's important that female entrepreneurs surround themselves with team members that have different strengths and expertise that can help run a successful business. Women think they can do it all themselves, and aren't thinking about team building and tapping resources the way that men are. Men in the business world tend to realize that, whereas women are used to multitasking.

- Build Relationships: Women often try to build relationships with prospective clients or customers, which can set themselves up for disappointment, Wesman said. "When they can't make the sale they take it too personally because it was a relationship they tried to build," she said. "Instead of stepping back and thinking, 'what did I learn from that sales experience?' or 'how can I use this to improve my next sales experience?" Wesman blames this on how women have been conditioned in society, and being uncomfortable with competition and wanting to be liked. "Then you take it really personally, because you are trying to sell based on people liking you," Wesman said. She said women need to build relationships, but shouldn't be scared to be competitive when pitching sales.
- Under-pricing services: Money can be a touchy subject for many women, Wes man said, and many have trouble discussing pricing terms. This uneasiness often leads females business owners to under value their products or services. "It does not understand what it actually costs you to produce a product, or what it costs you to deliver a service," Wes man said. "Women also under price themselves in the workplace, and the same thing happens when you are an entrepreneur."

- Hiding from cash flow issues: Managing cash flow and following up on owed money and payments is critical to every successful business, but women tend to be less assertive when it comes to collecting money, according to Wes man. "This goes along with the issue of it being unladylike, or not feminine to discuss money, or think about money, or to collect it," she said. Owners need to face those debtors head on, and get what they are due.

- Getting too close with employees: While many small businesses adopt that "family" mentality, female entrepreneurs are often very guilty of getting too close with their workers, Wes man said. "They treat employees like family and friends," she said. "It's about having a good business relationship, but not getting involved in too personal relationship." When a relationship reaches that point, it becomes harder to make decisions in the best interest of the business, she said.

\section{SOME CASES OF SUCCESSFUL INDIAN WOMEN ENTREPRENEURS:}

- Indra Nooyi Current position: CFO, Pepsico Indra Nooyi, 56, is the current chairman and CFO of the second largest food and beverage business, PepsiCo. born in Chennai, Indra did her Bachelor's in Science from Madras Christian College in 1974 and a Post Graduate Diploma in Management (MBA) from Indian Institute of Management, Calcutta in 1976. Beginning her career in India, Nooyi held product manager positions at Johnson \& Johnson and textile firm Mettur Beardsell. Nooyi joined PepsiCo in 1994 and was named president and CFO in 2001. She has been conferred with prestigious Padma Bhushan for her business achievements and being an inspiration to India's corporate leadership.

- Naina Lal Kidwai Current position: Group General Manager \& Country Head - HSBC, India, Naina Lal Kidwai,55, is presently the Group General Manager and Country Head of HSBC India. Naina has a Bachelor's degree in Economics from Delhi university and an MBA from Harvard Business school. In fact, Kidwai was the first Indian woman to graduate from Harvard Business School. She started her career with ANZ Grindlays. Presently, she is also serving as a nonexecutive director on the board of Nestle SA. Kidwai is also global advisor at Harvard Business school. Indian government conferred Padma Shri award on Naina for her contributions in the field of Trade and Industry. 
- Kiran Mazumdar Shaw Current position: CMD, Biocon Kiran,59, is the founder Chairman and Managing Director (CMD) of Biocon Limited. Born in Bangalore, Shaw completed her Bachelors in Zoology from Mount Carmel College, Bangalore University. She later did her post-graduation in Malting and Brewing from Ballarat College, Melbourne University. She worked as a trainee brewer in Carlton and United Breweries, Melbourne and as a trainee maltster at Barrett Brothers and Burston, Australia. She started Biocon in 1978 and spearheaded its evolution from an industrial enzymes manufacturing company to a fully integrated biopharmaceutical company. Today Biocon under Shaw's leadership has established itself as a leading player in biomedicine research with a focus on diabetes and oncology. Kiran is also a member of the board of governors of the prestigious Indian School of Business and Indian Institute of Technology Hyderabad. Kiran received the prestigious Padma Shri (1989) and the Padma Bhushan (2005) from the government of India.

- Vaidya Manohar Chhabria Chairman of Jumbo Group. The wife of a late Manohar Rajaram Chhabria is now leading Jumbo Group, a Dubai based Dollar 1.5 billion business conglomerate. She was ranked 38th most powerful women by the Fortune Magazine in 2003.

- Neelam Dhawan Managing Director Microsoft India. She is well known figure in IT Industry of India. Before joining Microsoft, she worked in almost all the top IT Companies.

- Lalita Gupte \& Kalpane Morparia Joint Managing Directors of ICICI Bank, have made immense contribution to the banking sector in India.

- Ekta Kappor Who is popularly known as the "soap queen", Creative Director of Balaji Telefilms is credited for bringing about a revolution in the Indian small screen industry. She is a rare combination of beauty and brain and a great inspiration for budding entrepreneurs.

- Shahnaz Hussain Current position: CEO, Shahnaz Herbals Inc, Shahnaz Hussain is the biggest name in herbal cosmetics industry in India. She has introduced a number of trend setting herbal products. Currently, the Shahnaz Husain Group has over 400 franchise clinics across the world covering over 138 countries. Her pioneering work got recognition from Govt of India when she was conferred with prestigious Padma Shri award in 2006 .

\section{CONCLUSION:}

It is observable that women entrepreneurs have proved to be a strong driving force in today's corporate world. They are competent to balance their duties of both motherhood and entrepreneurship but they comprise of almost half of all businesses owned today. Indian women and laws guaranteed equal rights of participation in political process and equal opportunities and rights in education and employment were enacted. But unfortunately, the government sponsored development activities have benefited only a small section of women i.e. the urban middle class women. Women sector occupies nearly $45 \%$ of the Indian population. At this juncture, effective steps are needed to provide entrepreneurial awareness, orientation and skill development programs to women. Woman can pick up a job any day, but if she becomes an entrepreneur she can provide a livelihood to 10 more women at least..!! Highly educated, technically sound and professionally qualified women must be encouraged for managing their own business, rather than being employed in any outlets. The uncultivated talents of young women can be identified, trained and exploited for various types of industries to increase the productivity in the industrial sector as well as the nation. Now a days even after facing so many obstacles The Indian women is now becoming educated and economically independent. Women entrepreneurs face so many problems from financial, marketing, health, family, and other problems point of view. The governments and financial institutions must enforce some measurable guidelines for women entrepreneurs from time to time. Women entrepreneurship must be moulded properly with entrepreneurial traits and skills to meet the changes in trends, challenges of the global markets and also be competent enough to sustain and strive for excellence in the entrepreneurial arena.

\section{REFERENCES :}

[1] Danish Ahmad Ansari, "Women Entrepreneurship in India (An empirical study)" AEIJST - April 2016

[2] Dr. C. Eugine Franco *1, Sharmi Selvakumar, "ENTREPRENEURSHIP - A KEY FOR WOMEN EMPOWERMENT" international journal of research, Granthalaya.

[3] Dr. MeenuMaheshwari, 2Ms. PriyaSodani, "Women Entrepreneurship- A Literature Review" IOSR Journal of Business and Management

[4] Dr.N. Thyagaraju, "WOMEN ENTREPRENEURSHIP DEVOLOPMENT PRACTICES" IN INDIA- A REVIEW" Original Research Paper, Assistant Professor, Department of commerce, Sri A.B.R Government Degree College, Repalle, GUNTUR

[5] Dr. Sunil Deshpande **Ms. Sunita Sethi, "Women Entrepreneurship In India" Research Paper-Commerce \& Management

[6] Dr. Vijayakumar, A. and Jayachitra, S., "WOMEN ENTREPRENEURS IN INDIA - EMERGING ISSUES AND CHALLENGES" International Journal of Development Research

[7] Jadhawrao Madhavi Sugaraj, Dr. Salve P.S. "A Study of Women Entrepreneurship and Their Problems in the Development in Western Maharashtra "IOSR Journal of Economics and Finance (IOSR-JEF)

[8] Priyanka Naira, Pankaj Gakharb, "Women Entrepreneurship: Finding Voice and Vision" IOSR Journal of Business and Management

[9] Seema Johar, "A study on the Development of Women Entrepreneurship in Ghaziabad, UP, India” International Journal of Applied And Pure Science and Agriculture

[10] V Krishnamoorthy1* and R Balasubramani2, "MOTIVATIONAL FACTORS AMONG WOMEN ENTREPRENEURS AND THEIR ENTREPRENEURIAL SUCCESS: A STUDY" International journal of management research and business strategy 